\title{
Update on the Treatment of Metastatic Squamous Non-Small Cell Lung Cancer in New Era of Personalized Medicine
}

\author{
Sara Victoria Soldera and Natasha B. Leigh/* \\ Division of Medical Oncology, Princess Margaret Cancer Centre, Toronto, ON, Canada
}

Despite advances in molecular characterization and lung cancer treatment in recent years, treatment options for patients diagnosed with squamous cell carcinoma of the lung (SCC) remain limited as actionable mutations are rarely detected in this subtype. This article reviews potential molecular targets and associated novel agents for the treatment of advanced SCC in the era of personalized medicine. Elements of various pathways including epidermal growth factor receptor, PI3KCA, fibroblast growth factor receptor, retinoblastoma, cyclin-dependent kinases, discoidin domain receptor tyrosine kinase 2 , and mesenchymal-to-epithelial transition may play pivotal roles in the development of SCC and are under investigation for drug development.

Edited by:

Vera Hirsh,

McGill University, Canada

Reviewed by:

Janaki Deepak, University of Maryland Baltimore,

USA

Jimson Wilson DSouza, Fox Chase Cancer Center, USA

*Correspondence:

Natasha B. Leighl natasha.leighl@uhn.ca

Specialty section: This article was submitted to

Thoracic Oncology, a section of the journal

Frontiers in Oncology

Received: 29 November 2016 Accepted: 09 March 2017

Published: 27 March 2017

Citation:

Soldera SV and Leighl NB (2017) Update on the Treatment of Metastatic Squamous Non-Small Cell

Lung Cancer in New Era of Personalized Medicine.

Front. Oncol. 7:50.

doi: 10.3389/fonc.2017.00050
Keywords: targeted therapy, personalized medicine, lung cancer, squamous cell carcinoma, molecular sequence data

\section{INTRODUCTION}

In 2016, lung cancer remains the most commonly diagnosed malignancy and accounts for the most cancer-related deaths worldwide, representing a significant global health burden (1). The majority of these neoplasms are pathologically categorized as non-small cell lung cancer (NSCLC), which is further divided into three main pathological subtypes: adenocarcinoma, squamous cell carcinoma (SCC), and large cell carcinoma. SCC represents an estimated $20 \%$ of NSCLC in developed countries and is mainly attributed to tobacco consumption (2). In the past decade, breakthroughs in molecular characterization of cancers have revolutionized the classification and therapeutic arsenal for lung malignancies. With the discovery of oncogenic driver mutations in epidermal growth factor receptor (EGFR) and rearrangements in anaplastic lymphoma kinase $(A L K)$ and ROS1, there has been a paradigm shift from a "one size fits all" approach to lung cancer treatment to more precise and rational targeted therapy $(3,4)$. Targeted agents such as EGFR and ALK tyrosine kinase inhibitors (TKI) are now routinely used in clinical practice and have contributed to improving the previously dismal prognosis of this malignancy (5-12). Unfortunately, the impact of these developments to date is largely limited to lung adenocarcinoma as these actionable mutations are rarely detected in other subtypes such as pure SCC (13). This article reviews potential molecular targets and associated novel treatments for advanced lung SCC in the new era of personalized medicine (Figure 1; Table 1).

In recent years, comprehensive molecular profiling of SCC has revealed that these cancers harbor numerous genomic and epigenomic alterations with a reported mean of 360 exonic mutations, 165 rearrangements, and 323 segments of copy-number alteration per tumor (14). Relative to 


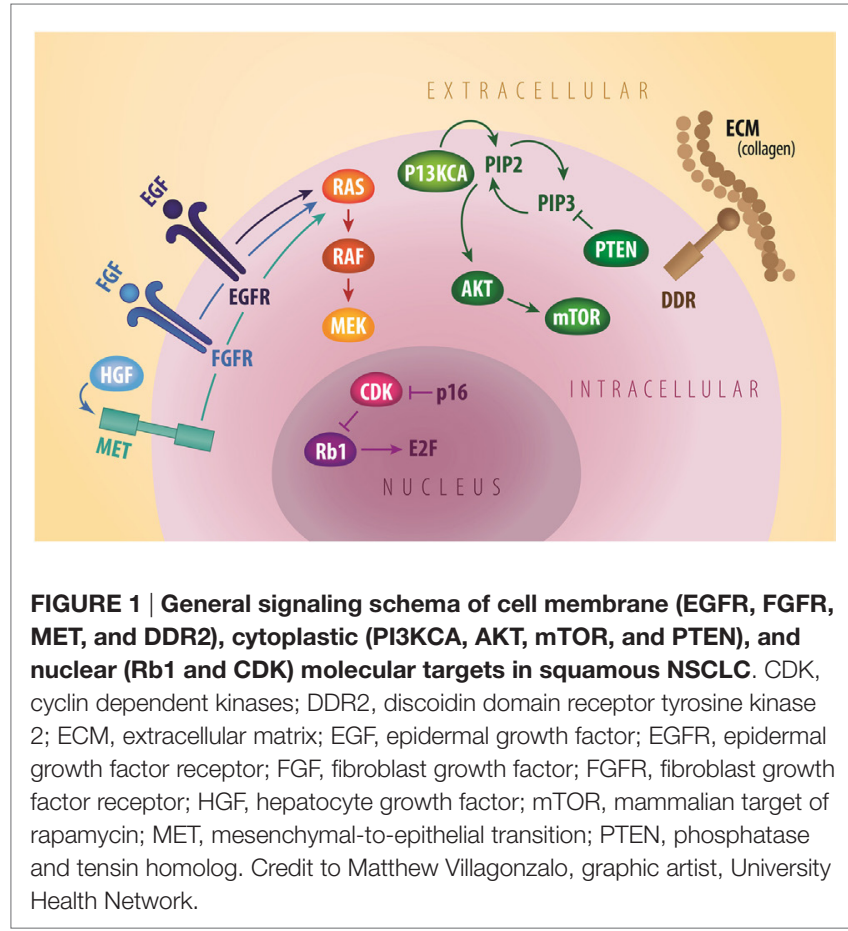

other tumor types, only malignant melanomas contain a higher burden of genetic abnormalities (24). This is not surprising since both of these cancers are associated with significant exposure to carcinogens. In fact, SCC is known to be strongly associated with chronic tobacco exposure (25). With such a complex genetic landscape and associated high immunogenicity, this tumor type has been an interesting target for immunotherapy and chemotherapy, but the development of targeted agents has thus far represented a significant challenge (26). To address this lack of targeted therapies, the Cancer Genome Atlas Project compared SCC samples to normal pulmonary tissue in order to identify potential actionable mutations (14). Eleven recurrent genomic abnormalities were reported, including tumor protein 53, cyclin-dependent kinase inhibitor $2 A$ (CDKN2A), phosphatase and tensin homolog (PTEN), PIK3CA, Kelch-like ECH-associated protein 1, mixed-lineage leukemia protein 2, human leukocyte antigens A, nuclear factor erythroid-derived 2-like 2, NOTCH1, and retinoblastoma ( $R b 1)$ (Figure 1; Table 1). Aberrations in these genes are thought to promote oncologic transformation and progression through their effect on cell survival and proliferation, cell cycle progression, metastatic spread, genetic instability, and response to oxidative stress. Other series have demonstrated similar recurring mutations, while also demonstrating significant abnormalities in Kirsten rat sarcoma viral oncogene homolog (KRAS), PI3KCA, mesenchymal-to-epithelial transition (MET), human epidermal growth factor receptor 2, fibroblast growth factor receptor (FGFR), platelet-derived growth factor receptors (PDGFR), BRAF, and discoidin domain receptor tyrosine kinase 2 (DDR2) $(15-23,27)$ (Figure 1; Table 1). These findings have fueled the development of multiple targeted agents directed against these pathways (Table 2).
TABLE 1 | Estimated incidence of targetable molecular aberrations in squamous non-small cell lung cancer (NSCLC).

\begin{tabular}{|c|c|c|}
\hline Gene and aberration & Incidence (\%) & Reference \\
\hline \multicolumn{3}{|l|}{ EGFR } \\
\hline \multirow[t]{3}{*}{ Mutation } & $0-4.9$ & Lindeman et al. (13) \\
\hline & 1.1 & TCGA (14) \\
\hline & 4 & Spoerke et al. (15) \\
\hline Amplification & 7 & TCGA (14) \\
\hline \multicolumn{3}{|l|}{ ALK } \\
\hline Rearrangement & 0 & Lindeman et al. (13) \\
\hline \multicolumn{3}{|l|}{ FGFR } \\
\hline \multirow[t]{2}{*}{ Mutation } & $0.8^{\mathrm{b}}$ & CLCGP/NGM (16) \\
\hline & $8^{c}$ & TCGA (14) \\
\hline \multirow[t]{2}{*}{ Amplification } & $9.7-22$ & Weiss et al. (17) \\
\hline & $16^{e}$ & Heist et al. (18) \\
\hline \multicolumn{3}{|l|}{ PI3KCA } \\
\hline \multirow[t]{2}{*}{ Amplification } & 37 & Spoerke et al. (15) \\
\hline & 33 & Yamamoto et al. (19) \\
\hline \multirow[t]{4}{*}{ Mutation } & 9 & Spoerke et al. (15) \\
\hline & 16 & TCGA (14) \\
\hline & 3.6 & Yamamoto et al. (19) \\
\hline & 6.5 & Kawano et al. (20) \\
\hline \multicolumn{3}{|l|}{ PTEN } \\
\hline Loss & 21 & Spoerke et al. (15) \\
\hline \multirow[t]{2}{*}{ Mutation } & 8 & TCGA (14) \\
\hline & 10.2 & Jin et al. (21) \\
\hline \multicolumn{3}{|l|}{ Rb1 } \\
\hline Mutation & 7 & TCGA (14) \\
\hline \multicolumn{3}{|l|}{ CDK } \\
\hline Amplification ${ }^{d}$ & Significantly amplified & TCGA (14) \\
\hline \multicolumn{3}{|l|}{ CDKN2A } \\
\hline Mutation & 15 & TCGA (14) \\
\hline $\operatorname{Loss}^{a}$ & 72 & TCGA (14) \\
\hline \multicolumn{3}{|l|}{ DDR2 } \\
\hline Mutation & 1.1 & CLCGP/NGM (16) \\
\hline & 3.8 & Hammerman et al. (22) \\
\hline
\end{tabular}

MET

amplification

$6.2-10.3$

Go et al. (23)

${ }^{a}$ Via epigenetic silencing by methylation, inactivating mutation, exon $1 \beta$ skipping and homozygous deletion.

${ }^{b}$ All FGFR3 mutations.

${ }^{c} F G F R 1,2,3$, and 4 mutations.

'Significant amplification of CDK6 and CCND1.

eFGFR1 amplification.

\section{EPIDERMAL GROWTH FACTOR RECEPTOR}

EGFR TKIs improve outcomes for patients with lung cancer harboring activating EGFR mutations. While these mutations are commonly found in adenocarcinoma, women, Asians and light or never smokers $(3,5-10)$, they are rarely found in pure SCC with series reporting a rate in the range of $0-5 \%$ (13). Despite this, EGFR TKI have shown significant benefit compared to placebo in patients with advanced lung cancer (all genotypes) having progressed on first or second-line chemotherapy, including SCC (28-30). More recently, Soria et al. reported further advantage of afatinib over erlotinib in the treatment of advanced unselected SCC (including mixed NSCLC) in terms of both PFS (median 2.6 versus 1.9 months; HR $0.81,95 \%$ CI $0.69-0.96, p=0.0103$ ) 
TABLE 2 | Clinical trials of targeted therapies in squamous NSCLC.

\begin{tabular}{|c|c|c|c|c|}
\hline \multirow[t]{2}{*}{ Agents } & \multirow[t]{2}{*}{ Trial } & \multirow[t]{2}{*}{ Phase } & \multirow{2}{*}{$\begin{array}{l}\text { Outcome } \\
(95 \% \mathrm{Cl})\end{array}$} & \multirow[t]{2}{*}{ Reference } \\
\hline & & & & \\
\hline \multicolumn{5}{|l|}{ EGFR } \\
\hline Erlotinib versus placebo & $\mathrm{BR} 21$ & III & OS HR 0.70 (0.58-0.85) & Shepherd et al. (28) \\
\hline Gefitinib versus D & INTEREST & III & OS HR 1.020 (0.905-1.150) & Kim et al. (29) \\
\hline Afatinib versus erlotinib & LUX-Lung 8 & III & $\begin{array}{l}\text { PFS HR } 0.81 \text { (0.69-0.96) } \\
\text { OS HR } 0.81 \text { (0.69-0.95) }\end{array}$ & Soria et al. (30) \\
\hline$C+T \pm$ cetuximab & BMS 099 & III & $\begin{array}{l}\text { PFS HR } 0.902 \text { (0.761-1.069) } \\
\text { OS HR } 0.890(0.754-1.051)\end{array}$ & Lynch et al. (31) \\
\hline Cis $+V \pm$ cetuximab & FLEX & III & OS HR 0.871 (0.762-0.996) & Pirker et al. (32) \\
\hline Chemo \pm cetuximab & Pujol et al. & Individual patient data meta-analysis & $\begin{array}{l}\text { PFS HR } 0.90(0.82-1.00) \\
\text { OS HR } 0.88(0.79-0.97)\end{array}$ & Pujol et al. (33) \\
\hline Cis $+\mathrm{G} \pm$ necitumumab & SQUIRE & III & OS HR $0.84(0.74-0.96)$ & Thatcher et al. (34) \\
\hline $\mathrm{P} \pm$ matuzumab (1 versus 3 week) & Schiller et al. & Randomized II & $\begin{array}{l}\text { ORR } 5 \text { versus } 11 \%(p=0.332)^{a} \\
\text { OS } 1 \text { week HR } 0.67(0.3-0.21) \\
\text { OS } 3 \text { week HR } 1.66(0.9-0.86)\end{array}$ & Schiller et al. (35) \\
\hline$C+T \pm$ panitumumab & Crawford et al. & Randomized II & TTP HR 0.9 (0.66-1.21) & Crawford et al. (36) \\
\hline \multicolumn{5}{|l|}{ FGFR } \\
\hline $\mathrm{D} \pm$ nintedanib & LUME-lung 1 & III & $\begin{array}{l}\text { PFS HR } 0.79 \text { (0.68-0.92) } \\
\text { OS HR } 0.94 \text { (0.83-1.05) }\end{array}$ & Reck et al. (37) \\
\hline Dovitinib & Lim et al. & Single arm ॥ & ORR 11.5\% (0.8-23.8) & Lim et al. (38) \\
\hline AZD4547 & Paik et al. & $\mathrm{lb}$ & 0 CR, 1 PR, 4 SD, 9 PD & Paik et al. (39) \\
\hline BGJ398 & Nogova et al. & I & $\begin{array}{l}\text { 15.4\% PR, 34.6\% SD } \\
\text { 23.1\% PR, 26.9\% unknown }\end{array}$ & Nogova et al. (40) \\
\hline \multicolumn{5}{|l|}{ PIЗKCA } \\
\hline Everolimus & Soria et al. & Single arm II & ORR $4.7 \%$ & Soria et al. (41) \\
\hline Everolimus + D & Ramalingam et al. & Single arm II & ORR 8\% & Ramalingam et al. (42) \\
\hline Erlotinib \pm everolimus & Besse et al. & Randomized II & PFS $0.769(0.506-1.167)$ & Besse et al. (43) \\
\hline Buparlisib & BASALT-1 & Single arm ॥ & 12 week PFS 23.3\% (9.9-42.3) & Vansteenkiste et al. (44) \\
\hline$D \pm P X-866$ & Levy et al. & Randomized II & $\begin{array}{l}\text { med PFS } 2 \text { versus } 2.9 \text { mo }(p=0.65) \\
\text { med OS } 7.9 \text { versus } 9.4 \text { mo }(p=0.9)\end{array}$ & Levy et al. (45) \\
\hline \multicolumn{5}{|l|}{$\mathrm{Rb} 1 / \mathrm{CDK}$} \\
\hline Palbociclib & Gopalan et al. & Single arm II & $\begin{array}{l}\text { ORR 0\%, SD } 50 \%(8 / 16) \\
\text { Med PFS } 12.5 \text { week }\end{array}$ & Gopalan et al. (46) \\
\hline Abemaciclib & Patnaik et al. & । & ORR 3\%, DCR 49\% & Patnaik et al. (47) \\
\hline \multicolumn{5}{|l|}{ DDR2 } \\
\hline Dasatinib & Johnson et al. & Single arm ॥ & $\begin{array}{l}\text { DCR 43\%, ORR 3\% } \\
\text { Med PFS } 1.36 \mathrm{mo} \\
\text { Med OS } 11.4 \mathrm{mo}\end{array}$ & Johnson et al. (48) \\
\hline Dasatinib + erlotinib & Haura et al. & $\mid / I I$ & $\begin{array}{l}\text { DCR } 62 \%, \text { ORR } 7 \% \\
\text { Med PFS } 2.7 \mathrm{mo} \\
\text { Med OS } 5.6 \mathrm{mo}\end{array}$ & Haura et al. (49) \\
\hline \multicolumn{5}{|l|}{ MET } \\
\hline $\mathrm{PL}+\mathrm{TAX} \pm$ onartuzumab & Hirsch et al. & Randomized II & $\begin{array}{l}\text { PFS HR } 0.95 \text { (0.63-1.43) } \\
\text { OS HR } 0.90(0.55-1.47)\end{array}$ & Hirsch et al. (50) \\
\hline Erlotinib \pm tivantinib & Sequist et al. & Randomized II & $\begin{array}{l}\text { PFS HR } 0.81(0.57-1.16) \\
\text { OS HR } 0.87 \text { (0.59-1.27) }\end{array}$ & Sequist et al. (51) \\
\hline Erlotinib \pm onartuzumab & METLung & III & $\begin{array}{l}\text { PFS HR } 0.99 \text { (0.81-1.20) } \\
\text { OS HR } 1.27(0.98-1.65)\end{array}$ & Spigel et al. (52) \\
\hline Erlotinib \pm onartuzumab & Spigel et al. & Randomized II & $\begin{array}{l}\text { PFS HR } 1.09 \text { (0.73-1.62) } \\
\text { OS HR } 0.80(0.50-1.28)\end{array}$ & Spigel et al. (53) \\
\hline
\end{tabular}

C, carboplatin; Cis, cisplatin; CR, complete response; D, docetaxel; DCR, disease control rate; G, gemcitabine; HR, hazard ratio; Med, median; ORR, objective response rate; OS, overall survival; P, pemetrexed; PD, progressive disease; PFS, progression-free survival; PL, platinum; PR, partial response; SD, stable disease; T, taxane; TAX, paclitaxel; TTP, time to progression; $V$, vinorelbine.

${ }^{a}$ ORR in pem versus all matuzumab containing arms.

${ }^{b}$ Represents number of patients with measured response as detailed.

and OS (median OS 7.9 versus 6.8 months; HR 0.81, 95\% CI $0.69-0.95, p=0.0077$ ) (30). Of note, patients were previously treated with first-line platinum doublet and had no prior EGFR TKI directed therapies.
Monoclonal antibodies directed against EGFR have also been investigated in this setting. For example, several trials explored the use of cetuximab in combination with chemotherapy in treatment naïve patients, including two phase III trials with conflicting 
results $(31,32)$. A meta-analysis reported a HR of $0.878(95 \%$ CI, $0.795-0.969 ; p=0.01$ ) for overall survival favoring the use of cetuximab in all lung cancer subtypes (33). Necitumumab, a second-generation recombinant human IgG1 monoclonal antibody, has also shown minor improvements in PFS and OS when added to gemcitabine/cisplatin first-line in advanced SCC versus gemcitabine/cisplatin alone (HR OS 0.84, 95\% CI 0.74-0.96; $p=0.01$ ) (34). No predictive markers of benefit were identified, although EGFR copy number may be promising (54). Conversely, other agents such as matuzumab and panitumumab have failed to show a benefit $(35,36)$. Despite the low frequency of actionable mutations, SCC shows high rates of EGFR amplification and protein expression that could explain these results (55-57). To date, different trials have reported inconsistent results using these findings as predictive biomarkers for response to EGFR directed therapies and their significance remains controversial (58).

\section{FIBROBLAST GROWTH FACTOR RECEPTOR}

Genomic abnormalities in the FGFR pathway have also been frequently reported in various malignancies including SCC of the lung (59). Most of these aberrations are FGFR amplifications with reported rates ranging from approximately $10-25 \%$, while mutations are present in approximately $0-8 \%$ of cases $(14,16-18)$. It is hypothesized that this family of transmembrane receptors participates in many cellular processes including cell survival, differentiation, migration, angiogenesis, tissue homeostasis and repair, and inflammation (60-62). Clinically, FGFR amplifications are associated with smoking history and worse prognosis in SCC (63). In recent years, multiple FGFR-directed molecules, including both selective and non-selective FGFR inhibitors, have been developed but remain investigational to date. In the phase III LUME-lung 1 trial, nintedanib, an oral multiple TKI targeting FGFR1-3, vascular endothelial growth factor receptor 1-3, PDGFR $\alpha$ and $\beta$, RET, FLT3, and Src family kinases, was investigated in combination with docetaxel after failure of first-line therapy versus placebo (37). Despite marginal improvement in PFS in the overall study population, OS benefit was limited to adenocarcinomas. Dovitinib, a multikinase inhibitor of FGFR1-3, VEGFR1-3, PDGFR $\beta$, c-KIT, and FLT3, investigated in a phase II trial of SCC lung cancers showed modest antitumor activity and acceptable toxicity profile with most common significant side effects including gastrointestinal toxicity (nausea, diarrhea, and anorexia), skin rash, and fatigue (38). Selective FGFR inhibitors, such as FGFR1-3 and VEGFR2 inhibitor AZD4547 and pan-FGFR inhibitor BGJ398, remain largely investigational, as early phase trials have reported mixed results in terms of efficacy $(39,40)$ (NCT00979134, NCT02154490, NCT02160041, NCT01004224). Other agents such as lucitanib (64) (NCT01283945, NCT02109016), ponatinib (NCT01935336), Bay1163877 (NCT02592785, NCT01976741), ARQ087 (NCT01752920), and JNJ-42756493 (NCT02699606) are also in development. Most trials enrolled molecularly enriched populations according to FGFR amplification. To date, there is however no standardized method or cut-off for amplification status with significant heterogeneity across trials.

\section{PI3KCA}

Alterations in the PI3KCA pathway have also been implicated in the development and progression of advanced lung cancer (14). Its activation, triggering downstream AKT and mammalian target of rapamycin signaling, has been linked to gene amplification and mutations, which are both found predominantly in SCC in the range of 35 and $3-15 \%$, respectively $(14,15,19-21)$. This pathway is also upregulated through inactivating mutations and loss of its negative regulator PTEN and rarely via AKT mutations $(14,21,65)$. In response to various growth factors, PI3KCAAKT-mTOR participates in many cellular functions including cell growth, proliferation, differentiation, motility, and survival (66). In preclinical models, cells harboring PI3KCA alterations present aggressive phenotype and express markers of epithelialto-mesenchymal transition (67). Clinically, these aberrations are also linked to EGFR inhibitor resistance (68). Previously, multiple trials have investigated the use of everolimus, an mTORC1 inhibitor, with disappointing results (41-43). Currently, various newer agents targeting this pathway are in development including isoform-specific and pan-isoform PI3KCA inhibitors, AKT inhibitors, and dual PI3KCA-mTOR inhibitors. Buparlisib, an oral inhibitor of class I PI3K ( $\alpha, \beta, \gamma$, and $\mathrm{d}$ ), showed disappointing response rates in a phase II trial meeting futility criteria despite enrichment for PI3KCA pathway activation positive tumors (44). In phase I trials of advanced solid tumors including NSCLC, pilaralisib, an oral pan-class I PI3K inhibitor, has shown acceptable toxicity profile both as a single agent and in combination with EGFR inhibitors with preliminary efficacy limited to monotherapy use $(69,70)$. PX-866, an irreversible pan-isoform inhibitor of PI3K, failed to show benefit in terms of PFS and OS in a randomized phase II trial in combination with docetaxel compared to placebo (45). Trials investigating other selective PI3K inhibitors such as taselisib (NCT02785913, NCT02389842, NCT02154490, NCT02465060) and pictilisib (NCT01493843, NCT02389842) are currently ongoing both as single agents and in combination with chemotherapy.

\section{Rb1 AND CYCLIN-DEPENDENT KINASES (CDK)}

The $R b 1$ pathway is also commonly disrupted in various cancers. In association with D-type CDK, CDK 4 and CDK6 promote cell cycle progression from the G1 to $\mathrm{S}$ phase via phosphorylation of the tumor suppressor $R b 1$. P16, a tumor suppressor protein encoded by CDKN2A, also influences this pathway through its negative regulation of CDK4 and CDK6, which ultimately causes inhibition of $\mathrm{Rb}$ phosphorylation. Once phosphorylated, $\mathrm{Rb}$ is rendered inactive, driving cells into synthesis thus contributing to oncogenesis. Deregulation of this pathway occurs as a result of various mechanisms in SCC including CDKN2A inactivation via promoter methylation, deletions, and mutations, $R b$ mutations and deletions, and CDK amplifications (14, 71-74). Furthermore, preclinical data suggest activity of CDK inhibitors in lung cancer xenograft models, and therefore, CDK4/6 inhibitors are currently under investigation for the treatment of advanced lung cancers (74). In a phase II trial, Gopalan et al. 
found no responses to palbociclib, a highly specific CDK4/6 inhibitor, in patients with advanced lung cancers and negative p16 expression by immunohistochemistry (46). Interestingly, approximately half of evaluable patients had stable disease (SD) suggesting treatment may induce replicative senescence. Abemaciclib, another CDK4/6 inhibitor, showed acceptable toxicity profile and preliminary efficacy in a phase I trial of multiple tumor types, including NSCLC (47). Further trials investigating these agents are currently underway (NCT02411591, NCT02450539, NCT02152631, NCT02079636, NCT02022982, NCT02389842, NCT02897375, NCT02785939).

\section{DISCOIDIN DOMAIN RECEPTOR TYROSINE KINASE 2}

Discoidin domain receptor tyrosine kinase 2 is a widely expressed receptor tyrosine kinase (RTK) in normal cells that is activated through its interaction with various types of extracellular matrix protein collagen. Once activated by ligand binding and phosphorylation, DDR2 has been shown to promote various cellular functions such as migration, differentiation, proliferation, and survival (75). This RTK has been proposed as a potential treatment target in various cancers. Sequencing data has in fact shown mutations in the kinase domain of DDR2 in approximately $1-4 \%$ of SCC $(16,22)$. Furthermore, in vitro studies have also demonstrated that cells harboring these mutations are sensitive to silencing of DDR2 by RNA interference. Multikinase inhibitors have been found to have DDR2 directed activity in cell lines (76). Dasatinib, a multikinase inhibitor that targets $B C R-A B L$, Src family, c-KIT, PDGFR- $\beta$, and ephrin receptor approved for the treatment of chronic myelogenous leukemia (CML), has been investigated for the treatment of NSCLC. Pitini et al. reported a case of a patient with DDR2 mutated SCC who presented a nearly complete response following treatment with dasatinib for a concurrent CML (77). In a phase II trial, this agent demonstrated moderate clinical activity in patients with unselected treatment naive advanced NSCLC (48). Its use was however limited by significant toxicity, in particular pleural effusion. Notably, one patient responded markedly to treatment with four others showing prolonged $\mathrm{SD}$, suggesting potential benefit in a subset of patients. Unfortunately, investigators failed to identify a predictive biomarker in this subpopulation of responders. Another phase II trial of dasatinib in combination with erlotinib in heavily pretreated NSCLC showed modest efficacy with two patients having $\mathrm{PR}$, one with an EGFR mutated adenocarcinoma and one with SCC (49). It is however challenging to estimate the antitumor activity of dasatinib in this setting as responses are more likely related to erlotinib.

\section{MESENCHYMAL-TO-EPITHELIAL TRANSITION}

The proto-oncogene $M E T$ is disrupted in various cancers including NSCLC (78). It encodes a RTK that, once activated by its ligand hepatocyte growth factor, promotes downstream signaling via multiple pathways such as PI3KCA, AKT, signal transducer and activator of transcription 3, and mitogen-activated protein kinase (79). Various activating alterations in MET have been reported in NSCLC. For example, MET amplification has been reported in approximately $6-10 \%$ of SCC, while mutations, particularly in exon 14, are more common in adenocarcinomas (23). Once upregulated, MET signaling contributes to cell survival, invasion, migration, and proliferation (79). Clinically, MET amplification has been linked to EGFR TKI resistance and poor prognosis (80). Cells harboring alterations in this pathway were found to be responsive to MET inhibitors that are commonly used in other tumor types such as crizotinib and cabozantinib $(81,82)$. Several clinical trials have investigated various TKI with MET directed activity for the treatment of advanced NSCLC with disappointing results in the SCC subpopulation so far (50-53). For example, onartuzumab, a monoclonal antibody directed against MET, failed to show significant antitumor activity in a phase II trial in combination with platinum-doublet chemotherapy (50). Moreover, a phase III trial of onartuzumab in combination with erlotinib was terminated early due to futility in terms of its primary outcome (OS) despite selection of patients with positive MET expression by immunohistochemistry (52). Tivantinib, a small-molecule MET inhibitor, showed modest antitumor activity in combination with erlotinib in unselected NSCLC (51). In subgroup analysis, benefit was however mostly noted in KRAS mutated patients and the subsequent phase III trial enrolled only non-squamous histology (83). Finally, identifying responding subpopulations represents a significant challenge in the development of these agents. In fact, selection of patients across trials has been inconsistent, with no clear definition of MET enriched populations. Overexpression has been defined using various methods including protein overexpression by immunohistochemistry, gene copy-number gain, and amplification by fluorescent in situ hybridization. Despite these challenges, multiple MET-directed molecules are currently under investigation for advanced NSCLC, including SCC (NCT02499614, NCT02034981, NCT00585195, NCT02925104, NCT02414139, NCT02929290, NCT02296879, etc).

\section{IMMUNE THERAPY}

In recent years, immunotherapy agents have elicited great interest for the treatment of several tumor types. Various immune checkpoint inhibitors including antibodies directed against cytotoxic T-lymphocyte associated protein 4, programmed cell death protein 1 (PD-1), and programmed death ligand-1 (PD-L1) are under investigation or approved for clinical practice, revolutionizing the approach to lung cancer treatment. Patients diagnosed with SCC in particular have benefited from these advancements, as alternative treatments are sparse, and they have higher mutation burden, which may be associated with benefit. Agents such as nivolumab, pembrolizumab, and atezolizumab have demonstrated improvement in survival outcomes in the second-line setting including in SCC (84-87). Furthermore, Pembrolizumab showed improvement both PFS and OS for patients with strongly PDL-1-expressing tumors treated in the first-line setting. This was however not the case for first-line nivolumab, another PD-1 inhibitor that used less restrictive PDL-1 selection, which had similar PFS and OS but not superior outcomes (88) 
(NCT02041533). Much like targeted agents, the selection of patients seems to be an important factor when choosing the best course of therapy. Unfortunately, a predictive biomarker to guide this decision is lacking with PD-L1 expression status, a promising biomarker for the selection of the subgroup likely to benefit from PD-1 and PD-L1 inhibiting drugs, having shown mixed results so far. For example, in the Checkmate 017 study of nivolumab in advanced pretreated SCC patients, PDL-1 expression was not predictive of benefit and even those without PDL-1 expression derived survival gain (84). Conversely, PD-L1 expression was predictive in the Checkmate 057 trial of nivolumab in a similar setting in non-squamous NSCLC (85). Finally, smoking status, a simple clinical characteristic, could also represent a possible predictive marker of response.

\section{CONCLUSION}

SCC represents complex tumors with alterations in various interacting pathways (14). Despite the current wealth of available molecular data and a vast array of clinical trial results, multiple challenges remain in the development of targeted therapies for this cancer. One recurring obstacle is the definition of subgroups that derive optimal benefit from investigational agents. With the current understanding of NSCLC now refined according to molecular profiles, individual subpopulations represent rare tumor types limiting their accrual into traditionally

\section{REFERENCES}

1. Ferlay J, Soerjomataram I, Ervik M, Dikshit R, Eser S, Mathers C, et al. GLOBOCAN 2012 v1.0, Cancer Incidence and Mortality Worldwide: IARC CancerBase No. 11 [Internet]. Lyon, France: International Agency for Research on Cancer (2013). Available from: http://globocan.iarc.fr

2. Howlader N, Noone AM, Krapcho M, Miller D, Bishop K, Altekruse SF, et al. SEER Cancer Statistics Review, 1975-2013. Bethesda, MD: National Cancer Institute (2016). Available from: http://seer.cancer.gov/csr/1975_2013/, based on November 2015 SEER data submission, posted to the SEER web site

3. Lynch TJ, Bell DW, Sordella R, Gurubhagavatula S, Okimoto RA, Brannigan BW, et al. Activating mutations in the epidermal growth factor receptor underlying responsiveness of non-small-cell lung cancer to gefitinib. $N$ Engl J Med (2004) 350:2129-39. doi:10.1056/NEJMoa040938

4. Soda M, Choi YL, Enomoto M, Takada S, Yamashita Y, Ishikawa S, et al. Identification of the transforming EML4-ALK fusion gene in non-small cell lung cancer. Nature (2007) 448:561-6. doi:10.1038/nature05945

5. Maemondo M, Inoue A, Kobayashi K, Sugawara S, Oizumi S, Isobe H, et al. Gefitinib monotherapy for non-small cell lung cancer with mutated EGFR. $N$ Engl J Med (2010) 362:2380-8. doi:10.1056/NEJMoa0909530

6. Rosell R, Carcereny E, Gervais R, Vergnenegre A, Massuti B, Felip E, et al. Erlotinib versus standard chemotherapy as first-line treatment for European patients with advanced EGFR mutation-positive non-small-cell lung cancer (EURTAC): a multicentre, open-label, randomised phase 3 trial. Lancet Oncol (2012) 13:239-44. doi:10.1016/S1470-2045(11)70393-X

7. Sequist LV, Yang JC, Yamamoto N, O’Byrne K, Hirsh V, Mok T, et al. Phase III study of afatinib or cisplatin plus pemetrexed in patients with metastatic lung adenocarcinoma with EGFR mutations. J Clin Oncol (2013) 31:3327-34. doi:10.1200/JCO.2012.44.2806

8. Wu YL, Zhou C, Hu CP, Feng J, Lu S, Huang Y, et al. Afatinib versus cisplatin plus gemcitabine for first-line treatment of Asian patients with advanced non-small-cell lung cancer harbouring EGFR mutations (LUX-Lung 6): an open-label, randomised phase 3 trial. Lancet Oncol (2014) 15:213-22. doi:10.1016/S1470-2045(13)70604-1 designed clinical trials. The revolutionized classification of lung cancer therefore requires an equally novel approach to clinical trial design. In fact, a growing number of "master protocols" with innovative schemes such as "basket" and "umbrella" biomarker-driven trials have been completed or are currently underway $(89,90)$ (NCT01042379). The LUNG-MAP trial, one such biomarker-based master protocol, is currently ongoing in multiple centers (90). Enrolled patients with advanced SCC are assigned to treatment arms according to detected targetable mutations identified through a comprehensive genomic profiling platform. Targeted agents such as taselisib, palbociclib, talazoparib, ABBV-399, rilotumumab, and AZD4547 have been included in this study. Furthermore, patients without actionable mutations are included in immune therapy sub-studies investigating various immune checkpoint inhibitors such as nivolumab, ipilimumab, durvalumab, and tremelimumab. Considering the dismal prognosis of patients diagnosed with advanced SCC, a greater focus on drug development and clinical trials remains of upmost importance to improve outcomes in this disease.

\section{AUTHOR CONTRIBUTIONS}

SS researched data for review topic, drafted manuscript, and edited manuscript revisions. NL researched data for review topic and edited manuscript.

9. Mok TS, Wu YL, Thongprasert S, Yang CH, Chu DT, Saijo N, et al. Gefitinib or carboplatin-paclitaxel in pulmonary adenocarcinoma. N Engl J Med (2009) 361:947-57. doi:10.1056/NEJMoa0810699

10. Han JY, Park K, Kim SW, Lee DH, Kim HY, Kim HT, et al. First-SIGNAL: firstline single-agent iressa versus gemcitabine and cisplatin trial in never-smokers with adenocarcinoma of the lung. J Clin Oncol (2012) 30:1122-8. doi:10.1200/ JCO.2011.36.8456

11. Shaw AT, Kim DW, Nakagawa K, Seto T, Crinó L, Ahn MJ, et al. Crizotinib versus chemotherapy in advanced ALK-positive lung cancer. $N$ Engl J Med (2013) 368:2385-94. doi:10.1056/NEJMoa1214886

12. Shaw AT, Kim DW, Mehra R, Tan DS, Felip E, Chow LQ, et al. Ceritinib in ALK-rearranged non-small-cell lung cancer. NEnglJ Med (2014) 370:1189-97. doi:10.1056/NEJMoa1311107

13. Lindeman NI, Cagle PT, Beasley MB, Chitale DA, Dacic S, Giaccone G, et al. Molecular testing guideline for selection of lung cancer patients for EGFR and ALK tyrosine kinase inhibitors: guideline from the College of American Pathologists, International Association for the Study of Lung Cancer, and Association for Molecular Pathology. J Thorac Oncol (2013) 8:823-59. doi:10.1097/JTO.0b013e318290868f

14. Cancer Genome Atlas Research Network. Comprehensive genomic characterization of squamous cell lung cancers. Nature (2012) 489:519-25. doi:10.1038/ nature 11404

15. Spoerke JM, O’Brien C, Huw L, Koeppen H, Fridlyand J, Brachmann RK, et al. Phosphoinositide 3-Kinase (PI3K) pathway alterations are associated with histologic subtypes and are predictive of sensitivity to PI3K inhibitors in lung cancer preclinical models. Clin Cancer Res (2012) 18:6771-83. doi:10.1158/1078-0432.CCR-12-2347

16. Clinical Lung Cancer Genome Project (CLCGP), Network Genomic Medicine (NGM). A genomics-based classification of human lung tumors. Sci Transl Med (2013) 5:209ra153. doi:10.1126/scitranslmed.3006802

17. Weiss J, Sos ML, Seidel D, Peifer M, Zander T, Heuckmann JM, et al. Frequent and focal FGFR1 amplification associates with therapeutically tractable FGFR1 dependency in squamous cell lung cancer. Sci Transl Med (2010) 2:62ra93. doi:10.1126/scitranslmed.3001451 
18. Heist RS, Mino-Kenudson M, Sequist LV, Tammireddy S, Morrissey L, Christiani DC, et al. FGFR1 amplification in squamous cell carcinoma of the lung. J Thorac Oncol (2012) 7:1775-80. doi:10.1097/JTO.0b013e31826aed28

19. Yamamoto H, Shigematsu H, Nomura M, Lockwood WW, Sato M, Okumura N, et al. PI3KCA mutations and copy number gains in human lung cancers. Cancer Res (2008) 68:6913-21. doi:10.1158/0008-5472.CAN07-5084

20. Kawano O, Sasaki H, Endo K, Suzuki E, Haneda H, Yukiue H, et al. PIK3CA mutation status in Japanese lung cancer patients. Lung Cancer (2006) 54:209-15. doi:10.1016/j.lungcan.2006.07.006

21. Jin G, Kim MJ, Jeon HS, Choi JE, Kim DS, Lee EB, et al. PTEN mutations and relationship to EGFR, ERBB2, KRAS, and TP53 mutations in nonsmall cell lung cancers. Lung Cancer (2010) 69:279-83. doi:10.1016/ j.lungcan.2009.11.012

22. Hammerman PS, Sos ML, Ramos AH, Xu C, Dutt A, Zhou W, et al. Mutations in the DDR2 kinase gene identify a novel therapeutic target in squamous cell lung cancer. Cancer Discov (2011) 1:78-89. doi:10.1158/2159-8274. CD-11-0005

23. Go H, Jeon YK, Park HJ, Sung SW, Seo JW, Chung DH. High MET gene copy number leads to shorter survival in patients with non-small cell lung cancer. J Thorac Oncol (2010) 5:305-13. doi:10.1097/JTO.0b013e3181ce3d1d

24. Alexandrov LB, Nik-Zainal S, Wedge DC, Aparicio SA, Behjati S, Biankin $\mathrm{AV}$, et al. Signatures of mutational processes in human cancer. Nature (2013) 500:415-21. doi:10.1038/nature12477

25. Dela Cruz CS, Tanoue LT, Matthay RA. Lung cancer: epidemiology, etiology, and prevention. Clin Chest Med (2011) 32:605-44. doi:10.1016/ j.ccm.2011.09.001

26. Masters GA, Temin S, Azzoli CG, Giaccone G, Baker S Jr, Brahmer JR, et al. Systemic therapy for stage IV non-small-cell lung cancer: American Society of Clinical Oncology clinical practice guideline update. J Clin Oncol (2015) 33:3488-515. doi:10.1200/JCO.2015.62.1342

27. Kan Z, Jaiswal BS, Stinson J, Janakiraman V, Bhatt D, Stern HM, et al. Diverse somatic mutation patterns and pathway alterations in human cancers. Nature (2010) 466:869-73. doi:10.1038/nature09208

28. Shepherd FA, Pereira JR, Ciuleanu T, Ciuleanu T, Tan EH, Hirsh V, et al. Erlotinib in previously treated non-small-cell lung cancer. N Engl J Med (2005) 353:123-32. doi:10.1056/NEJMoa050753

29. Kim ES, Hirsh V, Mok T, Socinski MA, Gervais R, Wu YL, et al. Gefitinib versus docetaxel in previously treated non-small-cell lung cancer (INTEREST): a randomised phase III trial. Lancet (2008) 372:1809-18. doi:10.1016/ S0140-6736(08)61758-4

30. Soria JC, Felip E, Cobo M, Lu S, Syrigos K, Lee KH, et al. Afatinib versus erlotinib as second-line treatment of patients with advanced squamous cell carcinoma of the lung (LUX-Lung 8): an open-label randomised controlled phase 3 trial. Lancet Oncol (2015) 16:897-907. doi:10.1016/S1470-2045(15) 00006-6

31. Lynch TJ, Patel T, Dreisbach L, McCleaod M, Heim WJ, Hermann RC, et al. Cetuximan and first-line taxane/carboplatin chemotherapy in advanced nonsmall-cell lung cancer: results of the randomized multicenter phase III trial BMS099. J Clin Oncol (2010) 28:911-7. doi:10.1200/JCO.2009.21.9618

32. Pirker R, Pereira JR, Szczesna A, von Pawel J, Krzakowski M, Ramlau R, et al. Cetuximab plus chemotherapy in patients with advanced non-small-cell lung cancer (FLEX): an open-label randomised phase III trial. Lancet (2009) 373:1525-31. doi:10.1016/S0140-6736(09)60569-9

33. Pujol JL, Pirker R, Lynch TJ, Butts CA, Rosell R, Shepherd FA, et al. Metaanalysis of individual patient data from randomized trials of chemotherapy plus cetuximab as first-line treatment for advanced non-small cell lung cancer. Lung Cancer (2014) 83:211-8. doi:10.1016/j.lungcan.2013.11.006

34. Thatcher N, Hirsch FR, Luft AV, Szczesna A, Ciuleanu TE, Dediu M, et al. Necitumumab plus gemcitabine and cisplatin versus gemcitabine and cisplatin alone as first-line therapy in patients with stage IV squamous nonsmall-cell lung cancer (SQUIRE): an open-label, randomised, controlled phase 3 trial. Lancet Oncol (2015) 16:763-74. doi:10.1016/S1470-2045(15) 00021-2

35. Schiller JH, von Pawel J, Schütt $\mathrm{P}$, Ansari RH, Thomas M, Saleh M, et al. Pemetrexed with or without matuzumab as second-line treatment for patients with stage IIIB/IV non-small cell lung cancer. J Thorac Oncol (2010) 5:1977-85. doi:10.1097/JTO.0b013e3181f4a5c9
36. Crawford J, Swanson P, Schwarzenberger P, Sandler A, Prager D, Zhang K, et al. A phase 2 randomized trial of paclitaxel and carboplatin with or without panitumumab for first-line treatment of advanced non-small-cell lung cancer. J Thorac Oncol (2013) 8:1510-8. doi:10.1097/JTO.0b013e3182a7d1da

37. Reck M, Kaiser R, Mellemgaard A, Douillard JY, Orlov S, Krzakowski M, et al. Docetaxel plus nintedanib versus docetaxel plus placebo in patients with previously treated non-small-cell lung cancer (LUME-Lung 1): a phase 3, double-blind, randomised controlled trial. Lancet Oncol (2014) 15:143-55. doi:10.1016/S1470-2045(13)70586-2

38. Lim SH, Sun JM, Choi YL, Kim HR, Ahn S, Lee JY, et al. Efficacy and safety of dovitinib in pretreated patients with advanced squamous non-small cell lung cancer with FGFR1 amplification: a single-arm, phase 2 study. Cancer (2016) 122:3024-31. doi:10.1002/cncr.30135

39. Paik PK, Shen R, Ferry D, Soria J-C, Mathewson A, Kilgour E, et al. Phase 1b open-label multicenter study of AZD4547 in patients with advanced squamous cell lung cancers: preliminary antitumor activity and pharmacodynamics data. J Clin Oncol (2014) 32(Suppl; abstr 8035).

40. Nogova L, Sequist LV, Cassier PA, Hidalgo M, Delord J-P, Schuler MH, et al. Targeting FGFR1-amplified lung squamous cell carcinoma with the selective pan-FGFR inhibitor BGJ398. J Clin Oncol (2014) 32(Suppl; abstr 8034).

41. Soria JC, Shepherd FA, Douillard JY, Wolf J, Giaccone G, Crino L, et al. Efficacy of everolimus (RAD001) in patients with advanced NSCLC previously treated with chemotherapy alone or with chemotherapy and EGFR inhibitors. Ann Oncol (2009) 20:1674-81. doi:10.1093/annonc/mdp060

42. Ramalingam SS, Owonikoko TK, Behera M, Subramanian J, Saba NF, Kono SA, et al. Phase II study of docetaxel in combination with everolimus for second-or third-line therapy of advanced non-small-cell lung cancer. J Thorac Oncol (2013) 8:369-72. doi:10.1097/JTO.0b013e318282709c

43. Besse B, Leighl N, Bennouna J, Papadimitrakopoulou VA, Blais N, Traynor AM, et al. Phase II study of everolimus-erlotinib in previously treated patients with advanced non-small-cell lung cancer. Ann Oncol (2014) 25:409-15. doi:10.1093/annonc/mdt536

44. Vansteenkiste JF, Canon JL, Braud FD, Grossi F, De Pas T, Gray JE, et al. Safety and efficacy of buparlisib (BKM120) in patients with PI3K pathway-activated non-small cell lung cancer: results from the phase II BASALT-1 study. J Thorac Oncol (2015) 10:1319-27. doi:10.1097/JTO.0000000000000607

45. Levy B, Spira A, Becker D, Evans T, Schnadig I, Camidge DR, et al. A randomized, phase 2 trial of docetaxel with or without px-866, an irreversible oral phosphatidylinositol 3-kinase inhibitor, in patients with relapsed or metastatic non-small-cell lung cancer. J Thorac Oncol (2014) 9:1031-5. doi:10.1097/ JTO.0000000000000183

46. Gopalan PK, Pinder MC, Chiappori A, Ivey AM, Villegas AG, Kaye FJ, et al. A phase II clinical trial of the CDK $4 / 6$ inhibitor palbociclib (PD 0332991) in previously treated, advanced non-small cell lung cancer (NSCLC) patients with inactivated CDKN2A. J Clin Oncol (2014) 32(Suppl; abstr 8077):5s.

47. Patnaik A, Rosen LS, Tolaney SM, Tolcher AW, Goldman JW, Gandhi L, et al. Efficacy and safety of abemaciclib, an inhibitor of CDK4 and CDK6, for patients with breast cancer, non-small cell lung cancer, and other solid tumors. Cancer Discov (2016) 6:740-53. doi:10.1158/2159-8290.CD-16-0095

48. Johnson FM, Bekele BN, Feng L, Wistuba I, Tang XM, Tran HT, et al. Phase II study of dasatinib in patients with advanced non-small-cell lung cancer. J Clin Oncol (2010) 28:4609-15. doi:10.1200/jco.2010.28.15_suppl.7594

49. Haura EB, Tanvetyanon T, Chiappori A, Williams C, Simon G, Antonia S, et al. Phase I/II study of the Src inhibitor dasatinib in combination with erlotinib in advanced non-small-cell lung cancer. JClin Oncol (2010) 28:1387-94. doi:10.1200/JCO.2009.25.4029

50. Hirsch FR, Govindan R, Zvirbule Z, Braiteh F, Rittmeyer A, Belda-Iniesta C, et al. Efficacy and safety results from a phase II, placebo-controlled study of onartuzumab plus first-line platinum-doublet chemotherapy for advanced squamous cell non-small-cell lung cancer. Clin Lung Cancer (2017) 18:43-9. doi:10.1016/j.cllc.2016.05.011

51. Sequist LV, von Pawel J, Garmey EG, Akerley WL, Brugger W, Ferrari D, et al. Randomized phase II study of erlotinib plus tivantinib versus erlotinib plus placebo in previously treated non-small-cell lung cancer. J Clin Oncol (2011) 29:3307-15. doi:10.1200/JCO.2010.34.0570

52. Spigel DR, Edelman MJ, O’Byrne K, Paz-Ares L, Shames DS, Yu W, et al. Onartuzumab plus erlotinib versus erlotinib in previously treated stage IIIb or IV NSCLC: results from the pivotal phase III randomized, multicenter, 
placebo-controlled METLung (OAM4971g) global trial. J Clin Oncol (2014) 32(Suppl; abstr 8000).

53. Spigel DR, Ervin TJ, Ramlau RA, Daniel DB, Goldschmidt JH Jr, Blumenschein GR Jr, et al. Randomized phase II trial of Onartuzumab in combination with erlotinib in patients with advanced non-small-cell lung cancer. J Clin Oncol (2013) 31:4105-14. doi:10.1200/JCO.2012.47.4189

54. Hirsch FR, Boyle TA, Thatcher N, Paz-Ares L, Varella-Garcia M, Kowalewski A, et al. EGFR IHC and FISH correlative analyses (SQUIRE trial): necitumumab + gemcitabine-cisplatin vs gemcitabine-cisplatin in 1st-line squamous NSCLC. 16th World Conference on Lung Cancer; Denver (2015). Sep 9. Abstract ORAL32.05.

55. Hirsch FR, Varella-Garcia M, Bunn PA Jr, Di Maria MV, Veve R, Bremmes RM, et al. Epidermal growth factor receptor in non-small-cell lung carcinomas: correlation between gene copy number and protein expression and impact on prognosis. JClin Oncol (2003) 21:3798-807. doi:10.1200/JCO.2003. 11.069

56. Dacic S, Flanagan M, Cieply K, Ramalingam S, Luketich J, Belani C, et al. Significance of EGFR protein expression and gene amplification in nonsmall cell lung carcinoma. Am J Clin Pathol (2006) 125:860-5. doi:10.1309/ H5UW6CPCWWC92241

57. López-Malpartida AV, Ludeña MD, Varela G, García Pichel J. Differential ErbB receptor expression and intracellular signaling activity in lung adenocarcinomas and squamous cell carcinomas. Lung Cancer (2009) 65:25-33. doi:10.1016/j.lungcan.2008.10.009

58. Uramoto H, Mitsudomi T. Which biomarker predicts benefit from EGFRTKI treatment for patients with lung cancer? Br J Cancer (2007) 96:857-63. doi:10.1038/sj.bjc.6603665

59. Dienstmann R, Rodon J, Prat A, Perez-Garcia J, Adamo B, Felip E, et al. Genomic aberrations in the FGFR pathway: opportunities for targeted therapies in solid tumors. Ann Oncol (2014) 25:552-63. doi:10.1093/annonc/ mdt419

60. Lewin J, Siu LL. Development of fibroblast growth factor receptor inhibitors: kissing frogs to find a prince? J Clin Oncol (2015) 33:3372-4. doi:10.1200/ JCO.2015.62.7380

61. Salgia R. Fibroblast growth factor signaling and inhibition in non-small cell lung cancer and their role in squamous cell tumors. Cancer Med (2014) 3:681-92. doi:10.1002/cam4.238

62. Bono F, De Smet F, Herbert C, De Bock K, Georgiadou M, Fons P, et al. Inhibition of tumor angiogenesis and growth by a small-molecule multi-FGF receptor blocker with allosteric properties. Cancer Cell (2013) 23:477-88. doi:10.1016/j.ccr.2013.02.019

63. Kim HR, Kim DJ, Kang DR, Lee JG, Lim SM, Lee CY, et al. Fibroblast growth factor receptor 1 gene amplification is associated with poor survival and cigarette smoking dosage in patients with resected squamous cell lung cancer. JClin Oncol (2013) 31:731-7. doi:10.1200/JCO.2012. 43.8622

64. Soria JC, DeBraud F, Bahleda R, Adamo B, Andre F, Dienstmann R, et al. Phase I/IIa study evaluating the safety, efficacy, pharmacokinetics, and pharmacodynamics of lucitanib in advanced solid tumors. Ann Oncol (2014) 25:2244-51. doi:10.1093/annonc/mdu390

65. Papadimitrakopoulou V. Development of PI3K/AKT/mTOR pathway inhibitors and their application in personalized therapy for non-small-cell lung cancer. J Thorac Oncol (2012) 7:1315-26. doi:10.1097/JTO.0b013e $31825493 \mathrm{eb}$

66. Cantley LC. The phosphoinositide 3-kinase pathway. Science (2002) 296:16557. doi:10.1126/science.296.5573.1655

67. Bonelli MA, Cavazzoni A, Saccani F, Alfieri RR, Quaini F, La Monica $\mathrm{S}$, et al. Inhibition of PI3K pathway reduces invasiveness and epithelial-to-mesenchymal transition in squamous lung cancer cell lines harboring PIK3CA gene alterations. Mol Cancer Ther (2015) 14:1916-27. doi:10.1158/ 1535-7163.MCT-14-0892

68. Huang L, Fu L. Mechanisms of resistance to EGFR tyrosine kinase inhibitors. Acta Pharm Sin B (2015) 5:390-401. doi:10.1016/j.apsb.2015.07.001

69. Soria JC, LoRusso P, Bahleda R, Lager J, Liu L, Jiang J, et al. Phase I dose-escalation study of pilaralisib (SAR245408, XL147), a pan-class I PI3K inhibitor, in combination with erlotinib in patients with solid tumors. Oncologist (2015) 20:245-6. doi:10.1634/theoncologist.2014-0449

70. Shapiro GI, Rodon J, Bedell C, Kwak EL, Baselga J, Braña I, et al. Phase I safety, pharmacokinetic, and pharmacodynamic study of SAR245408
(XL147), an oral pan-class I PI3K inhibitor, in patients with advanced solid tumors. Clin Cancer Res (2014) 20:233-45. doi:10.1158/1078-0432.CCR13-1777

71. Asghar U, Witkiewicz AK, Turner NC, Knudsen ES. The history and future of targeting cyclin-dependent kinases in cancer therapy. Nat Rev Drug Discov (2015) 14:130-46. doi:10.1038/nrd4504

72. Ohtani N, Yamakoshi K, Takahashi A, Hara E. The p16INK4a-RB pathway: molecular link between cellular senescence and tumor suppression. J Med Invest (2014) 51:146-53. doi:10.2152/jmi.51.146

73. Matsushime H, Quelle DE, Shurtleff SA, Shibuya M, Sherr CJ, Kato JY. D-type cyclin-dependent kinase activity in mammalian cells. Mol Cell Biol (1994) 14:2066-76. doi:10.1128/MCB.14.3.2066

74. Sherr CJ, Beach D, Shapiro GI. Targeting CDK4 and CDK6: from discovery to therapy. Cancer Discov (2016) 6:353-67. doi:10.1158/2159-8290.CD-15-0894

75. Leitinger B. Molecular analysis of collagen binding by the human discoidin domain receptors, DDR1 and DDR2 identification of collagen binding sites in DDR2. J Biol Chem (2003) 278:16761-9. doi:10.1074/jbc.M301370200

76. Day E, Waters B, Spiegel K, Alnadaf T, Manley PW, Buchdunger E, et al. Inhibition of collagen-induced discoidin domain receptor 1 and 2 activation by imatinib, nilotinib and dasatinib. Eur J Pharamacol (2008) 599:44-53. doi:10.1016/j.ejphar.2008.10.014

77. Pitini V, Arrigo C, Di Mirto C, Mondello P, Altavilla G. Response to dasatinib in a patient with SQCC of the lung harboring a discoid-receptor-2 and synchronous chronic myelogenous leukemia. Lung Cancer (2013) 82:171-2. doi:10.1016/j.lungcan.2013.07.004

78. Sadiq AA, Salgia R. MET as a possible target for non-small-cell lung cancer. J Clin Oncol (2013) 31:1089-96. doi:10.1200/JCO.2012.43.9422

79. Birchmeier C, Birchmeier W, Gherardi E, Vande Woude GF. Met, metastasis, motility and more. Nat Rev Mol Cell Biol (2003) 4:915-25. doi:10.1038/ nrm1261

80. Engelman JA, Zejnullahu K, Mitsudomi T, Song Y, Hyland C, Park JO, et al. MET amplification leads to gefitinib resistance in lung cancer by activating ERBB3 signaling. Science (2007) 316:1039-43. doi:10.1126/science. 1141478

81. Ou SH, Kwak EL, Siwak-Tapp C, Dy J, Bergethon K, Clark JW, et al. Activity of crizotinib (PF02341066), a dual mesenchymal-epithelial transition (MET) and anaplastic lymphoma kinase (ALK) inhibitor, in a non-small cell lung cancer patient with de novo MET amplification. J Thorac Oncol (2011) 6:942-6. doi:10.1097/JTO.0b013e31821528d3

82. Paik PK, Drilon A, Fan P, Yu H, Rekhtman N, Ginsberg MS, et al. Response to MET inhibitors in patients with stage IV lung adenocarcinomas harboring MET mutations causing exon 14 skipping. Cacner Discov (2015) 5:842-9. doi:10.1158/2159-8290.CD-14-1467

83. Scagliotti G, von Pawel J, Novello S, Ramlau R, Favaretto A, Barlesi F, et al. Phase III multinational, randomized, double-blind, placebo-controlled study of tivantinib (ARQ 197) plus erlotinib versus erlotinib alone in previously treated patients with locally advanced or metastatic nonsquamous non-small-cell lung cancer. J Clin Oncol (2015) 33:2667-74. doi:10.1200/ JCO.2014.60.7317

84. Brahmer J, Reckamp KL, Baas P, Crinò L, Eberhardt WE, Poddubskaya E, et al. Nivolumab versus docetaxel in advanced squamous-cell nonsmall-cell lung cancer. N Engl J Med (2015) 373:123-35. doi:10.1056/ NEJMoa1504627

85. Borghaei H, Paz-Ares L, Horn L, Spigel DR, Steins M, Ready NE, et al. Nivolumab versus docetaxel in advanced nonsquamous nonsmall-cell lung cancer. N Engl J Med (2015) 373:1627-39. doi:10.1056/ NEJMoa1507643

86. Herbst RS, Baas P, Kim DW, Felip E, Pérez-Gracia JL, Han JY, et al. Pembrolizumab versus docetaxel for previously treated, PD-L1-positive, advanced non-small-cell lung cancer (KEYNOTE-010): a randomised controlled trial. Lancet (2016) 387:1540-50. doi:10.1016/S0140-6736(15) 01281-7

87. Fehrenbacher L, Spira A, Ballinger M, Kowanetz M, Vansteenkiste J, Mazieres J, et al. Atezolizumab versus docetaxel for patients with previously treated non-small-cell lung cancer (POPLAR): a multicentre, open-label, phase 2 randomised controlled trial. Lancet (2016) 387:1837-46. doi:10.1016/ S0140-6736(16)00587-0

88. Reck M, Rodriguez-Abreu D, Robinson AG, Hui R, Csőszi T, Fülöp $A$, et al. Pembrolizumab versus chemotherapy for PD-L1-positive 
non-small-cell lung cancer. N Engl J Med (2016) 375:1823-33. doi:10.1056/ NEJMoa1606774

89. Kim ES, Herbst RS, Wistuba II, Lee JJ, Blumenschein GR Jr, Tsao A, et al. The BATTLE trial: personalizing therapy for lung cancer. Cancer Discov (2011) 1:44-53. doi:10.1158/2159-8274.CD-10-0010

90. Herbst RS, Gandara DR, Hirsch FR, Redman MW, LeBlanc M, Mack PC, et al. Lung master protocol (Lung-MAP) - a biomarker-driven protocol for accelerating development of therapies for squamous cell lung cancer: SWOG S1400. Clin Cancer Res (2015) 21:1514-24. doi:10.1158/1078-0432.CCR-13-3473
Conflict of Interest Statement: SS: none, NL: none known (honoraria for CME from Pfizer, Merck; travel funding for CME from Astrazeneca).

Copyright $\odot 2017$ Soldera and Leighl. This is an open-access article distributed under the terms of the Creative Commons Attribution License (CC BY). The use, distribution or reproduction in other forums is permitted, provided the original author(s) or licensor are credited and that the original publication in this journal is cited, in accordance with accepted academic practice. No use, distribution or reproduction is permitted which does not comply with these terms. 